\title{
Uterine Corpus Adenosarcoma Pathologic TNM Finding v8
}

National Cancer Institute

\section{Source}

National Cancer Institute. Uterine Corpus Adenosarcoma Pathologic TNM Finding v8. NCI Thesaurus. Code C139847.

A pathologic finding about one or more characteristics of uterine corpus adenosarcoma, following the rules of the TNM AJCC v8 classification system. 